\title{
The Effect of COVID-19 Pandemic on the Anxiety Levels of Internal Medicine Physicians and Practise of Internal Medicine Clinics
}

\author{
Yasemin KAYA ${ }^{1}$, Sedat BOSTAN ${ }^{2}$, Harun DÜĞEROĞLU ${ }^{3}$, Muhammet ÖZBILEN ${ }^{4}$, \\ Havva KESKIN ${ }^{5}$
}

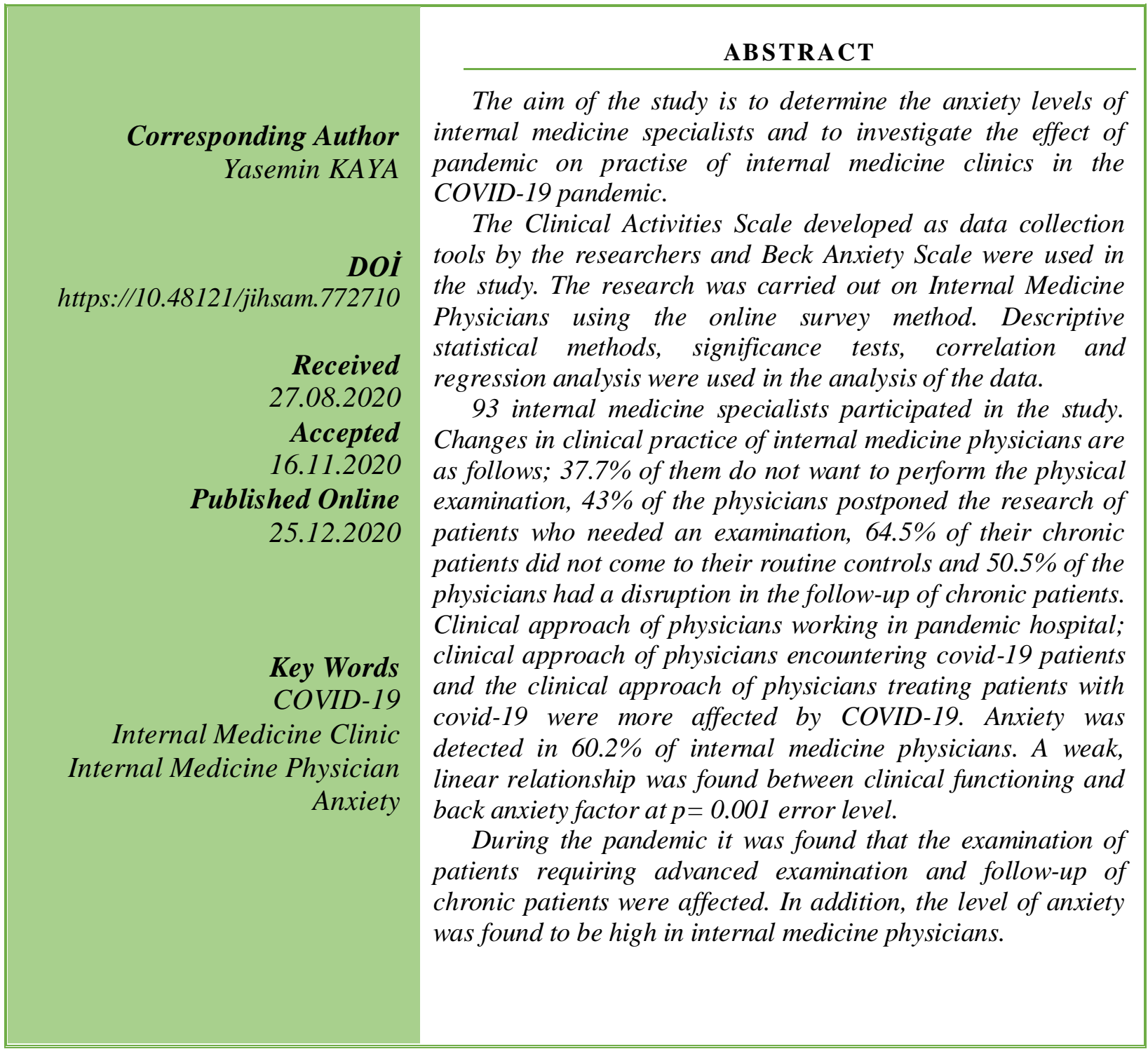

\footnotetext{
Assoc. Prof., Faculty of Medicine, Ordu University, Ordu. ysmnkcmz@ gmail.com. https://orcid.org/0000-0001-7360-8090

2 Assoc. Prof., Faculty of HealthSciences, Ordu University, Ordu. sbostan29@ gmail.com. https://orcid.org/0000-0002-9439-8448

3 Assoc. Prof., Faculty of Medicine, Ordu University, Ordu. Harun.dugeroglu@ hotmail.com. https://orcid.org/0000-0002-0546-175X

${ }^{4}$ Specialist, Ordu University -Ministry of Health Training and Research Hospital Clinic of Internal Medicine, Ordu. muhammetozbilen@yahoo.com.https://orcid.org/0000-0001-9845-7938

5 Specialist, Istanbul Medeniyet University Göztepe Training and Research Hospital, Clinic of Internal Medicine, Istanbul. havvadrkeskin@gmail.com.https://orcid.org/0000-0003-1794-4473
} 


\section{INTRODUCTION}

COVID-19 infection, which occurred in Wuhan city of China in December 2019 and caused by SARS$\mathrm{CoV}-2$, has affected many countries spreading rapidly from person to person (Rothan and Byrareddy,2020:26; Ding, 2020:10). The infection presents clinical courses ranging from asymptomatic and mild upper respiratory tract infection to severe respiratory failure and severe pneumonia, which may result in death (Zhou,2020:395). In addition, it has been observed that acute respiratory distress syndrome (ARDS) develops in COVID-19 infection more than influenza pneumonias and requires longer mechanical ventilation (Tolksdorf, 2020:25). Therefore, it has become a global public health problem as a potentially fatal disease (Rothan and Byrareddy,2020:26; Ding, 2020:10).

It has been specified that the virus is transmitted from person to person through droplets formed as a result of cough (Aysan,2020; Rothan and Byrareddy,2020:26). This virus can survive for a maximum of 4-5 days on various materials such as aluminum, wood, paper, plastic and glass according to the researchers. After touching the contaminated surfaces, transmission was also observed by touching one's own face (Aysan,2020; Cai, 2020:26). Fecal-oral transmission may also occur as the patients' feces contains virus particles (Aysan,2020). Since they are also transmitted through droplets or contaminated surfaces and contaminated blood, feces, etc., healthcare professionals are at serious risk of contamination (Aysan,2020). It has been observed that this situation causes serious tension and anxiety among healthcare professionals.

Generalized anxiety disorder (GAD) is a chronic, common disease characterized by uncontrollable excessive anxiety, worry, tension, and vigilance. It causes deterioration in the social relations and professional affairs of the person in daily life (Asoğlu, 2018:6; American Psychiatric Press; 1994; Miloyan, 2015:30; Kartal, 2009:13) It follows with symptoms such as restlessness, being on bed of nails constantly, fatigue, difficulty focusing or mind discharge, easy to get angry, muscle tension and sleep disturbance (Asoğlu,2018:6).

It was aimed to determine the anxiety levels of the internal medicine physicians in the COVID-19 pandemic and to investigate the effect of the pandemic on the functioning of the internal medicine clinics in this study.

\section{MATERIALS AND METHODS}

The study started after the approval taken from Ordu University Clinical Research Ethics Committee (2020/83).

How the pandemic reflects on internal medicine physicians and clinics in this duration when COVID19 pandemics continued in Turkey and in the world constituted the subject of the research. In this duration, social isolation and social distance applications were applied as legal requirements. The research was a descriptive study and the data was collected by quantitative method.

\section{The Population and Sampling of the Study}

The study population consisted of actively working internal medicine specialist students, specialists and academic physicians in Turkey. Data collection could only be performed using digital tools via the internet under these conditions. For this reason, the data of the study were collected through a questionnaire consisting of the internal medicine clinical activity scale and Beck Anxiety Inventory. Announcements were realized through social media networks for participation in the survey. Since the researchers were not have the opportunity to determine the participants in the digital environment, simple sampling method was used for data collection. Data collection period started on 1 May and ended on 30 May. The total period was about 30 days. During this period, 93 valid surveys were reached.

\section{Data Collection Tools}

The questionnaire given in the study consisted of three parts: demographic information, "COVID-19 Pandemic Internal Medicine Clinic Activity Scale" and "Beck Anxiety Inventory".

Demographic Information: It consisted of questions about the personal characteristics of internal medicine physicians, the types of hospitals they work in, the situation of encountering COVID-19 outbreak and providing service.

COVID-19 Pandemic Internal Medicine Clinic Activity Scale: The scale was prepared by conducting preliminary interviews with internal medicine specialists in the light of the literature review and information about the pandemic and taking the opinions of the academicians on the subject regarding the scope and structuring of questions.

SPSS program was used in the validity and reliability analysis of the scale. Factor analysis was performed to understand the construct validity of the items of the scale. Kaiser-Meyer-Olkin (KMO) test was carried out for the sample size and it was found to be 0.589 . Also, the results of Barlett's sphericity test were examined to find out whether the correlation between the items was significant and it was found to be significant at the level of 0.001 (approx. ChiSquare: 371.313 / df: 120 / sig: 0.000). In order to dimension the items, "Varimax" rotation process was 
applied with the "principal components" method. From the scale prepared as 23 statements, 7 statements were excluded because they did not bear sufficient factor load. Scale items were found to have factor loads between 0.408 and 0.815 .16 statements in the scale were collected under 3 factors. These factors were named as Clinical Approach (4 statements), Operation of the Clinic (7 expressions) and Protection (5 statements) factors. The variance explanation level of the factors forming the scale was calculated as 44.3\%. Cronbach's Alpha coefficient was examined for the reliability analysis of the clinical activity scale and this value was found to be 0.656. Back Anxiety Inventory was validated with confirmatory factor analysis. For the reliability analysis of the scale, Cronbach's Alpha coefficient was examined and this value was found to be 0.959 . It was understood that Cronbach's Alpha coefficient of the study was greater than 0.60 and therefore had reliability.

The analysis of the data was analyzed by frequency, significance and correlation tests in SPSS package program.

\section{RESULTS}

The findings of this study, which was conducted to determine the effect of COVID-19 pandemic on the internal diseases clinic activities in terms of internal medicine physicians, were as follows.

The Frequency Table of the Participants' Descriptive Variables was given in Table 1. When the data in Table 1 was examined, it was detected that 93 internal medicine physicians participated in the study, and $65.6 \%$ of these physicians were male, $77.4 \%$ of them were 39 years old and under, $62 \%$ of them worked as internal medicine specialist for 1-5 years, $59.1 \%$ of them worked in Ministry of Health hospitals and $59.2 \%$ of them were specialist physicians. The status of the internal medicine physicians participating in the study were as follows in terms of COVID-19 cases. $59.1 \%$ of internal medicine physicians worked in a pandemic hospital. Of internal medicine physicians, $80.6 \%$ encountered the patients with COVID-19; $74.2 \%$ served the patients with COVID19, $18.5 \%$ was tested for COVID-19, and the test result of all of them was negative. In addition, it was stated that four internal medicine physicians were in quarantine and two physicians recovered.

Table 1. Descriptive Variables of Internal Medicine Physicians

\begin{tabular}{|c|c|c|c|c|c|}
\hline Variable & $\mathbf{N}$ & $\%$ & Variable & $\mathbf{N}$ & $\%$ \\
\hline \multicolumn{3}{|l|}{ 1. Gender } & \multicolumn{3}{|l|}{ 6. Is your hospital a pandemic hospital? } \\
\hline Female & 32 & 34,4 & Yes & 62 & 59,1 \\
\hline Male & 61 & 65,6 & No & 14 & 15,1 \\
\hline \multicolumn{3}{|l|}{ 2.Age } & $\begin{array}{l}\text { Not a pandemic hospital, but there are COVID-19 } \\
\text { patients }\end{array}$ & 17 & 18,3 \\
\hline 39 and below & 72 & 77,4 & \multicolumn{3}{|c|}{ 6. Have you ever encountered patients with COVID-19? } \\
\hline $40-49$ & 21 & 22,6 & Yes & 75 & 80,6 \\
\hline $50-59$ & - & - & No & 18 & 19,4 \\
\hline \multicolumn{3}{|c|}{$\begin{array}{l}\text { 3. Working Years as Internal Medicine } \\
\text { Physician }\end{array}$} & \multicolumn{3}{|l|}{ 7. Have you ever treated the COVID-19 patient? } \\
\hline $1-5$ year & 57 & 62 & Yes & 69 & 74,2 \\
\hline $6-10$ year & 13 & 14,1 & No & 24 & 25,8 \\
\hline $11-15$ year & 13 & 14,1 & \multicolumn{3}{|l|}{ 8. Did you take the COVID 19 test? } \\
\hline $16-20$ year & 9 & 9,8 & Yes & 26 & 18,5 \\
\hline 21 and over year & - & - & No & 67 & 81,5 \\
\hline \multicolumn{3}{|l|}{ 4. Hospital You Work } & \multicolumn{3}{|l|}{ 9. If you did, what is the result of the COVID 19 test? } \\
\hline Ministry of Health Hospital & 55 & 59,1 & Pozitif & 0 & 0 \\
\hline University Hospital & 33 & 35,5 & Negative & 26 & 100 \\
\hline Private Hospital & 5 & 5,4 & \multicolumn{3}{|l|}{ 10. If you got COVID-19, your condition? } \\
\hline \multicolumn{3}{|l|}{ 5. Academic Title } & I spend without symptoms, in quarantine & 4 & \\
\hline Assistant Doctor & 31 & 33,3 & I receive inpatient treatment in the hospital & - & - \\
\hline Specialist Doctor & 55 & 59,2 & I recovered & 2 & \\
\hline Doctor Faculty Member & 7 & 7,5 & & & \\
\hline
\end{tabular}

In order to understand how the internal medicine clinics continue to operate during the pandemic, the findings of the study conducted on a five-point Likert scale and collected from three factors were given in Table 2. The arithmetic means and the frequency distributions of the internal medicine clinical activity scale were shown in the table to figure out the details of the findings. When Table 2 was examined, it has been observed that pandemic issues were prominent in the clinical approach. Of internal medicine physicians, $43.1 \%$ received a separate consent form related to COVID-19 for patients admitted to the clinic, $86 \%$ of 
them primarily questioned the symptoms of COVID19 in the patient examination, $11.9 \%$ of them made COVID-19 test to the patients of internal medicine clinic, and $31.3 \%$ had the patients performed torax computed tomography.

The statements of internal medicine physicians regarding the clinical operations were as follows. Of them, $37.7 \%$ stated that they avoided physical examination, $43 \%$ expressed that the patients requiring an examination delayed the research process, $60.2 \%$ enounced that cancer pre-diagnosed patients did not postpone their further examinations, $64.5 \%$ told that chronic patients did not come to their routine controls, and $50.5 \%$ stated that chronic patients' follow-up processes were disrupted. It was expressed that the new guidelines for $75.3 \%$ of physicians and the severity of the pandemic for $82.8 \%$ of physicians became effective in determining the treatment method. Of internal medicine physicians, $63.5 \%$ declared that they did not suffer from protective equipment, $72.1 \%$ stated that they used the equipment correctly, $60.2 \%$ expressed that they were in positive solidarity with their colleagues, and $75.3 \%$ told that they were successful in combating pandemics as a country.

It was figured out from the t-test and ANOVA test that genders, ages, working durations, the types of hospitals worked and the status of having COVID-19 test of internal medicine physicians did not affect the scale factors. It was observed that Asst. Prof. Dr. physicians had more positive views than assistant physicians in the protection factor at $p=0.003$ level. It was seen that whether the hospital where the internal medicine physicians worked was a pandemic hospital $(\mathrm{p}=0.026)$, encountering with the patient with COVID-19 ( $\mathrm{p}=0.004)$ and serving patients with COVID-19 ( $\mathrm{p}=0.005)$ caused significant differences in clinical approach. Clinical approaches of those working in the pandemic hospital, those who encountered patients with COVID-19 and who served patients with COVID-19 were more affected by COVID-19.

Table 2. The Frequency Distributions Of The Internal Medicine Clinical Activity Scale

\begin{tabular}{|c|c|c|c|c|c|c|c|c|c|c|c|c|}
\hline \multirow{3}{*}{ Expressions } & \multicolumn{10}{|c|}{$\begin{array}{c}\text { Investigation Of The Effect Of COVID-19 Pandemic On } \\
\text { Activities İn Internal Medicine Clinic }\end{array}$} & \multirow{3}{*}{$\overline{\mathbf{X}}$} & \multirow{3}{*}{ SS } \\
\hline & \multicolumn{2}{|c|}{$\begin{array}{l}\text { Never } \\
\text { Agree }\end{array}$} & \multicolumn{2}{|c|}{$\begin{array}{l}\text { Do Not } \\
\text { Agree }\end{array}$} & \multicolumn{2}{|c|}{$\begin{array}{l}\text { Partially } \\
\text { Agree }\end{array}$} & \multicolumn{2}{|c|}{ Agree } & \multicolumn{2}{|c|}{$\begin{array}{l}\text { Totally } \\
\text { Agree }\end{array}$} & & \\
\hline & $\mathbf{N}$ & $\%$ & $\mathbf{N}$ & $\%$ & $\mathbf{N}$ & $\%$ & $\mathbf{N}$ & $\%$ & $\mathrm{~N}$ & $\%$ & & \\
\hline Clinical Approach & & & & & & & & & & & 3,01 & $\mathbf{0 , 8 8}$ \\
\hline $\begin{array}{l}\text { We take COVID-19 related consent form from } \\
\text { patients who are admitted to hospitalization. }\end{array}$ & 30 & 32,3 & 8 & 8,6 & 15 & 16,1 & 6 & 6,5 & 34 & 36,6 & 3,06 & 1,71 \\
\hline $\begin{array}{l}\text { When accepting cases in the pandemic process, I first } \\
\text { question the symptoms of COVID-19. }\end{array}$ & 3 & 3,2 & 3 & 3,2 & 7 & 7,5 & 25 & 26,9 & 55 & 59,1 & 4,3 & 0,98 \\
\hline $\begin{array}{l}\text { When accepting cases in the pandemic process, I first } \\
\text { get a coronavirus test.. }\end{array}$ & 40 & 43 & 28 & 30,1 & 14 & 15,1 & 6 & 6,5 & 5 & 5,4 & 2,01 & 1,15 \\
\hline $\begin{array}{l}\text { While accepting the cases in the pandemic process, I } \\
\text { first have a CT scan and wait for the result. }\end{array}$ & 28 & 30,1 & 18 & 19,4 & 17 & 18,3 & 21 & 22,6 & 9 & 9,7 & 2,62 & 1,37 \\
\hline Clinical Procedure & & & & & & & & & & & 3,47 & 0,61 \\
\hline $\begin{array}{l}\text { I do not fully perform physical examination for all } \\
\text { patients during the pandemic process }\end{array}$ & 12 & 12,9 & 20 & 21,5 & 26 & 28 & 26 & 28 & 9 & 9,7 & 3 & 1,18 \\
\hline $\begin{array}{l}\text { I postpone the research process of patients who need } \\
\text { advanced examination in the pandemic process. }\end{array}$ & 9 & 9,7 & 9 & 9,7 & 35 & 37,6 & 28 & 30,1 & 12 & 12,9 & 3,26 & 1,11 \\
\hline $\begin{array}{l}\text { During my pandemic, I think that the most recent } \\
\text { guidelines affect my treatment method. }\end{array}$ & 3 & 3,2 & 3 & 3,2 & 17 & 18,3 & 24 & 25,8 & 46 & 49,5 & 4,15 & 1,04 \\
\hline $\begin{array}{l}\text { I think that the severity of COVID-19 is most } \\
\text { effective on my treatment during pandemic. }\end{array}$ & - & - & 6 & 6,5 & 10 & 10,8 & 37 & 39,8 & 40 & 43 & 4,1 & 0,87 \\
\hline $\begin{array}{l}\text { I postpone further examinations of patients who are } \\
\text { considered to have a pre-diagnosis of cancer during } \\
\text { the pandemic process }\end{array}$ & 33 & 35,5 & 23 & 24,7 & 18 & 19,4 & 13 & 14 & 6 & 6,5 & 2,31 & 1,26 \\
\hline $\begin{array}{l}\text { Patients with chronic disease I follow before } \\
\text { pandemic do not come for routine control. }\end{array}$ & 2 & 2,2 & 3 & 3,2 & 28 & 30,1 & 33 & 35,5 & 27 & 29 & 3,8 & 0,95 \\
\hline $\begin{array}{l}\text { We are experiencing serious disruptions in the follow- } \\
\text { up of patients with chronic disease that I followed } \\
\text { before pandemic. }\end{array}$ & 6 & 6,5 & 11 & 11,8 & 29 & 31,2 & 23 & 24,7 & 24 & 25,8 & 3,5 & 1,18 \\
\hline Fight against and Preventing COVID-19 in the Clinic & & & & & & & & & & & $3, \mathbf{8 8}$ & 0,69 \\
\hline $\begin{array}{l}\text { I do not have protective equipment shortage when } \\
\text { examining pandemic patients }\end{array}$ & 5 & 5,4 & 13 & 14 & 16 & 17,2 & 33 & 35,5 & 26 & 28 & 3,66 & 1,18 \\
\hline I use protective equipment correctly. & - & - & 4 & 4,3 & 22 & 23,7 & 33 & 35,5 & 34 & 36,6 & 4 & 0,88 \\
\hline $\begin{array}{l}\text { I think that we have a positive solidarity with our } \\
\text { colleagues during the pandemic process. }\end{array}$ & 4 & 4,3 & 12 & 12,9 & 21 & 22,6 & 29 & 31,2 & 27 & 29 & 3,67 & 1,15 \\
\hline $\begin{array}{l}\text { I think we are successful as a health system in the } \\
\text { fight against pandemic. }\end{array}$ & 1 & 1,1 & 2 & 2,2 & 20 & 21,5 & 36 & 38,7 & 34 & 36,6 & 4,07 & 0,87 \\
\hline $\begin{array}{l}\text { I think we are successful as a country in fighting } \\
\text { pandemic }\end{array}$ & 2 & 2,2 & 7 & 7,5 & 14 & 15,1 & 41 & 44,1 & 29 & 31,2 & 3,94 & 0,98 \\
\hline
\end{tabular}


The results of Beck Anxiety Inventory, which were performed to understand the anxiety levels of internal medicine physicians during the pandemic period, were given in Table 3. According to the table, it was observed that $39 \%$ of internal medicine physicians did not have anxiety, $25.8 \%$ of them had mild, $20.4 \%$ of them had moderate anxiety and $14 \%$ of them had severe anxiety.

Table 3. Evaluation of Physician's Back Anxiety Scales

\begin{tabular}{lrr}
\hline Back Anxiety Scales & N & \% \\
\hline No & 37 & 39,8 \\
Mild & 24 & 25,8 \\
Moderate & 19 & 20,4 \\
Severe & 13 & 14 \\
\hline
\end{tabular}

The correlation association between three factors of the clinical activity scale and the factor of Beck Anxiety Inventory was examined and the results were given in Table 4. Accordingly, a weak linear correlation was found between the clinical approach and the protection factor at $\mathrm{p}=0.001$ error level. The change in the clinical approach creates a change in the protection factor in the same direction although it was weak. A weak linear correlation was detected between the clinical operation factor and Beck Anxiety factor at $\mathrm{p}=0.001$ error level. Anxiety levels of internal medicine physicians increased as the change in clinical operation increased.

Table 4. Correlation of the Relationship between Scale Factors

\begin{tabular}{|l|l|l|l|l|}
\hline & $\begin{array}{c}\text { Clinical } \\
\text { Approach }\end{array}$ & $\begin{array}{c}\text { Clinical } \\
\text { Procedure }\end{array}$ & Prevention & $\begin{array}{c}\text { Back } \\
\text { Anxiety }\end{array}$ \\
\hline Clinical Approach & 1 & & & \\
\hline Clinical Procedure & 0.115 & 1 & & \\
\hline Prevention & $0.209(*)$ & 0.058 & 1 & \\
\hline Back Anxiety & 0.042 & $0.279(* *)$ & -0.068 & 1 \\
\hline
\end{tabular}

* Correlation is significant at the 0.05 level (2-tailed)

** Correlation is significant at the 0.01 level (2-tailed)

\section{DISCUSSION}

In this study conducted on internal medicine specialists, it was detected that $80.6 \%$ of 93 internal medicine specialists participating in the study encountered COVID-19 patients and $74.2 \%$ of them served to the patients with COVID-19. In addition, as a result of the survey, four internal medicine physicians declared that they were in quarantine $(4.3 \%)$ and two physicians $(2.1 \%)$ stated that they were recovered. It was observed that contamination was found at $6.4 \%$ of internal medicine specialists. Internal medicine specialists had a high rate of encountering with COVID-19 positive patients and following COVID-19 positive patients, and so they are at high risk. As a result of the studies performed, it has been emphasized that the viral load is an important factor in the development of different clinical findings in patients infected with COVID-19 as well as the personal factors belonging to the patients, and the viral load has effects on both mortality and duration of hospital stay (Pan, 2020; Zou 2020; Lung, 2009:80). It is stated that asymptomatic cases or cases with few symptoms, as well as in symptomatic patients, carry a risk of contagiousness (Aysan, 2020). For these reasons, healthcare professionals, especially physician groups such as internal medicine specialists having high rate of encountering with COVID-19 positive patients and following COVID-19 positive patients, are at serious risk for both COVID-19 transmission and viral load when infected.
Increased workload in the health system, physical exhaustion in healthcare professionals, inadequate personal equipment, taking rational decisions in the follow-up and treatment of patients or in the operation of the hospital during SARS pandemic had serious physical and mental negative effects on healthcare workers. Apart from that, the risk of infection transmission, isolation or loss of friends and relatives, and frequent disturbing changes in the working system have been shown to affect healthcare professionals negatively (Lung, 2009:80). In the studies conducted on the health professionals during 2003 SARS pandemic, healthcare professionals reported that they experienced fear of transmitting the infection to their families, friends, and colleagues, uncertainty, fear of stigma, unwillingness to go to work, thinking about resignation, and signs of high levels of stress, anxiety, and depression that may have long-term psychological effects (Maunder, 2003:168; Bai, 2004:55; Lee, 2007:52). Healthcare professionals, who are directly involved in the diagnosis, treatment and care of patients with COVID-19 and at serious risk of contamination and virus load, are particularly vulnerable to mental health problems such as fear, anxiety, depression and insomnia.

In epidemiological studies in the United States, the lifetime prevalence of Generalized Anxiety Disorder (GAD) in the community was found between $5.1 \%$ and $11.9 \%$ (Asoğlu, 2018:6). In another publication, it 
was reported that the lifetime prevalence of GAD in the community was 3-6\% (Alç1, 2019:22). As a result of this study, it was observed that internal medicine physicians had high anxiety at a rate of $60.2 \%$, especially $34.4 \%$ of them was moderate and severe.

When the clinical operation of internal medicine was examined during the pandemic period, it was detected that physical examinations were avoided at a rate of $37.7 \%$, the research process of patients requiring further examination was delayed at a rate of $43 \%, 60.2 \%$ of chronic patients did not come to routine control, and follow-ups of patients were at a rate of $50.5 \%$. It was observed that the high anxiety rate detected in internal medicine physicians significantly affected the clinical operation.

It was understood that whether the hospital where the internal medicine physicians worked was a pandemic hospital $(\mathrm{p}=0.026)$, encountering with the patient with COVID-19 (p = 0.004) and serving patients with COVID-19 (p=0.005) caused significant differences in clinical approach. Clinical approaches of those working in the pandemic hospital, those who encountered patients with COVID-19 and who served patients with COVID-19 were more affected by COVID-19.

\section{Limitations}

Due to social isolation, the fact that the test could be performed face to face and only online systems were used as a data collection tool was an important limitation. Moreover, the fact that physicians did not want to fill the test due to the excessive workload and the number of participants was low due to these reasons was considered as another reason for limitation.

\section{Conclusion and Recommendations}

High anxiety was detected in internal medicine specialist physicians, who had a high incidence of encountering with COVID-19 positive patients and following-treating COVID-19 positive patients, and therefore at high risk for transmission and virus load. Clinical approaches of those working in the pandemic hospital, who encountered patients with COVID-19 and who served patients with COVID-19, were found to be more affected than COVID-19.

Giving psychological support to internal medicine specialists in whom high anxiety develops during the pandemic period is necessary both for internal medicine specialists and for preventing undesired disruptions in clinical operation.

\section{Acknowledgments: None}

Conflict of Interest: The authors declare that they have no conflict of interest.

Ethical Approval: Approval was received from the Ethics Committee of Ordu University Clinical Researches

\section{Funding: None}

\section{REFERENCES}

Alçı D, Aydın O, Aydemir Ö.(2019) Reliability and validity of Turkish version of DSM-5 Generalized Anxiety Disorder scale Klinik Psikiyatri. 22:389-395

Guze SB (1994). Diagnostic and Statistical Manual of Mental Disorders. 4th ed. American Psychiatric Association Washington DC 873pp

Asoğlu M, Karka İ, Pirinççioğlu F, Göbelek M, Çelik H, Takatak H, et al.(2018) Cultural Reflections Of The Expressions Of The Anxiety Of Patients With Generalized Anxiety Disorder. Bezmialem Science 6(4): 242-7

Aysan AF, Balcı E, Karagöl ET, Kılıç E, Gültekin F, Sahin F et al. (2020) Bölüm:Tarihçe, Terminoloji, Tanımlar ve Türkiye'de Mevcut Durum. Türkiye Bilimler Akademisi. Covid-19 Pandemi Değerlendirme Raporu. Edt: Şeker M, Özer A, Tosun Z.

Bai Y, Lin CC, Lin CY, Chen JY, Chue CM, Chou P.(2004) Survey of stres reactions among health care workers involved with the SARS outbreak. Psychiatr Serv.55(9):1055-1057.

Cai J, Sun W, Huang J, Gamber M, Wu J, He G.(2020) Indirect Virus Transmission in Cluster of COVID-19 Cases, Wenzhou, China, 2020. Emerg Infect Dis.26(6):1343-1345.

Ding Q, Lu P, Fan Y, Xia Y, Liu M (2020) The clinical characteristics of pneumonia patients coinfected with 2019 novel coronavirus and influenza virus in Wuhan, China. Journal of Medical Virology. 20;10.1002/jmv.25781. doi: 10.1002/jmv.25781

Kartal M, Özçakar N.(2009) Yaygın anksiyete bozukluğu: Birinci basamakta görülme sıklığı ve tanı güçlükleri. Türkiye Aile Hekimliği Dergisi.13(4):206-209

Lee AM, Wong JG, McAlonan GM, Cheung V, Cheung C, Sham PC et al. (2007) Stress and psychological distress among SARS survivors 1 year after the outbreak. Can J Psychiatry. 52(4):233-240.
Liu Y, Yan LM, Wan L, Xiang TX, Le A, Liu JM et al. (2020) Viral dynamics in mild and severe cases of COVID-19. Lancet Infect Dis. DOI:https://doi.org/10.1016/S1473-3099(20)30232- 2

Lung FW, Lu YC, Chang YY, Shu BC. (2009) Mental symptoms in different health professionals during the SARS attack: A Follow-upstudy. Psychiatric Quarterly 80 (2):107-116

Maunder R, Hunter J, Vincent L, Bennett J, Peladeau N, Leszcz M et al. (2003) The immediate psychological and occupational impact of the 2003 SARS outbreak in a teaching hospital. CMAJ.168(10):1245-1251

Miloyan B, Pachana NA. (2015) Clinical significance of worry and physical symptoms in late-life generalized anxiety disorder. Int J GeriatrPsychiatry 30: 1186-94.

Pan Y, Zhang D, Yang P, Poon LLM ,Wang Q.(2020) Viral load of SARS-CoV-2 in clinical samples. Lancet Infect Dis. https://doi.org/10.1016/S1473-3099(20)30113-4

Rothan HA, Byrareddy SN.(2020) The epidemiology and pathogenesis of coronavirus disease (COVID-19) outbreak. J Autoimmun. 26:102433. doi: 10.1016/j.jaut.2020.102433

Tolksdorf K, Buda S, Schuler E, Wieler LH, Haas W.(2020) Influenza-associated pneumonia as reference to assess seriousness of coronavirus disease (COVID-19). Euro Surveill 25(11):2000258.

Zhou F, Yu T, Du R, Fan G, Liu Y, Liu Z et al.(2020) Clinical course and risk factors for mortality of adult in patients with COVID-19 in Wuhan, China: a retrospective cohort study. Lancet 395(10229):1054-62.

Zou L, Ruan F, Huang M, Liang L, Huang H, Hong $Z$ et al.(2020) SARS-CoV-2 viral load in upper respiratory specimens of infected patients. N Engl J Med. DOI:10.1056/NEJMc2001737 